INDEPENDENT JOURNAL OF MANAGEMENT \& PRODUCTION (IJM\&P)

http://www.ijmp.jor.br

v. 12, n. 5, July-August 2021

ISSN: 2236-269X

DOI: 10.14807/ijmp.v12i5.1395

\title{
INVESTIGATING HOW CONSUMER EDUCATION AND LIFESTYLE INFLUENCE THE CONSUMER EMPOWERMENT: CASE IN RURAL AND URBAN AREAS, INDONESIA
}

\author{
Megawati Simanjuntak \\ Department of Family and Consumer Sciences, \\ Faculty of Human Ecology, IPB University, Indonesia \\ E-mail:mega_juntak@apps.ipb.ac.id \\ Ulfah Mubarokah \\ Department of Family and Consumer Sciences, \\ Faculty of Human Ecology, IPB University, Indonesia \\ E-mail: ulfahmubarokah@gmail.com \\ Submission: $7 / 23 / 2020$ \\ Revision: 9/1/2020 \\ Accept: 9/14/2020
}

\section{ABSTRACT}

This study aimed to analyze the difference of consumer education, lifestyle, and consumer empowerment in rural and urban areas, and to analyze the effect of consumer education and lifestyle on the consumer empowerment. This research used a cross-sectional design study with 120 housewives as the sample selected purposively. Data were analyzed using independent sample t-test, MannWhitney, and multiple linear regressions. There were significant differences $(p<0.01)$ in consumer education, fulfilled lifestyle, believer lifestyle, and consumer empowerment index between the two regions, where the urban area scores were higher compared to the rural area. Consumer education and length of education affected positively and significantly $(p<0.01)$ on the consumer empowerment index, while the lifestyle did not significantly affect the consumer empowerment index. The higher intensity of consumer education and higher education levels will increase the consumer empowerment index.

Keywords: consumer education; consumer empowerment; lifestyle 
DOI: 10.14807/ijmp.v12i5.1395

\section{INTRODUCTION}

Consumers are currently in an increasingly complex market, information, and diverse selection regarding the goods and services (Simanjuntak et al., 2014). The development of accessing information provides convenience for consumers to obtain goods/services desired. However, access to information is used by sellers for unfair trade practices so that consumers become victims of dishonest promotions. This is evident in many cases of consumer loss. Nurhayati and Elisabeth (2011) mentioned 30 cases of consumer losses in goods trade and 31 cases of loss in property and services trade. The most prominent loss cases are in property business (36\%), vehicle buying (20\%), food (16\%), and some household appliances (8\%). Various incidents that violate consumer rights still often occur in many sectors; sometimes, even consumers are not aware that their rights are being violated. The incidents that have occurred have been varied, from simple to complex cases (Safari \& Simanjuntak, 2020). This condition proves that access to consumer education is crucial to be done so that consumers do not experience losses.

The main problem of consumers today is the low level of consumer awareness of their rights. This potentially reduces the ability of consumers to protect themselves from fraudulent business actors (Isaac \& Zabil, 2012; Kurniawan, 2012). Based on research data from the Australian Government (2011), 87\% of respondents do not know about their rights as consumers. According to PAIM et al. (2012), awareness about consumer rights will increase along with the amount of information obtained from consumer education.

Consumer education is one of the means to form skilled and conscious consumers toward their rights (Nardo et al., 2011). Simanjuntak et al. (2014) indicate that access to consumer education obtained by consumers living in the city and urban areas is still low, and there is a marked difference between the two regions. Factors that hinder information seeking are self, ignorance, and laziness (Juaini, Sinaga \& Rainathami, 2012). This condition shows that the socialization of consumer education is essential, considering the low level of consumer education access. Weak consumer education can be measured by looking at the consumer empowerment index. Low access to consumer education can also be seen from the broad openness of consumers to new things. Consumer lifestyle may indicate their openness to new ideas.

The fulfilled lifestyle shows the lifestyles of a responsible, professional, educated, highincome consumer, always aware of the development of the outside world, and very open to new information and social change (Thogersen, 2005). Therefore, the fulfilled lifestyle may 
INDEPENDENT JOURNAL OF MANAGEMENT \& PRODUCTION (IJM\&P)

http://www.ijmp.jor.br

v. 12, n. 5, July-August 2021

ISSN: 2236-269X

DOI: 10.14807/ijmp.v12i5.1395

reflect the power of consumers because of the many opportunities to gain access to such education.

Based on the above problems, it is necessary to empower consumers to become consumers who can submit their complaints at the time of disadvantage and can assert their rights (Nardo et al., 2011). Consumer empowerment is a positive subjective state generated by consumers through increased control (Wathieu, Benner \& Carmon, 2002). According to Wright, Newman, and Dennis (2006), consumers are considered to be empowered if they can defend their rights. Consumer empowerment can be promoted through government regulation and consumer education (Hunter \& Garnefeld, 2008). Factors affecting empowerment are the level of education (Suja, 2012, Pratama, 2013, Simanjuntak et al., 2014), geographic location (Chandrasekhar, 2012), income (Tayde \& Chole, 2010), and age (Nardo et al., 2011).

The research results of Simanjuntak et al. (2014) show that consumers who live in rural and urban areas are yet less empowered, and there is a significant difference between the two regions. The lowest dimensions of consumer empowerment are consumer firmness, the experience of unfair business practices, and the fulfillment of consumer rights. In contrast, the best aspect that reflects consumer empowerment is consumer skills. This illustrates that consumers who live in urban and rural areas have not been empowered.

Several studies have also been carried out to determine the empowerment of Indonesian consumers. Specifically, the consumer empowerment index in generation Y reaches 53.84 of the index (Simanjuntak, 2015). Thematic measurement of consumer empowerment indexes is carried out in several sectors. The research results show that the average index of consumer empowerment in the food sector 38.63 (Simanjuntak, 2018), formal education 54.34 (Simanjuntak \& Umiyati, 2021), telecommunications 51.6 (Simanjuntak \& Putri, 2020), online shopping 49.7 (Simanjuntak, 2019; Simanjuntak \& Musyifah, 2016), electronic products 41.78 (Simanjuntak \& Putri, 2018), services in the health sector 48.85 (Simanjuntak \& Yuja, 2021). Of all the studies conducted, the lowest dimension is in the behavior of complaints. This is supported by other research that focuses on complaint behavior which concludes that consumer complaint behavior is still lacking when experiencing disappointment with business actors (Simanjuntak, 2019; Wandani \& Simanjuntak, 2019). Thus, the complaints behavior which is still very low as part of the indicator of consumer empowerment, needs more attention (Simanjuntak \& Hamimi, 2019).

Based on the empirical studies above, consumer empowerment is an attractive research topic concerning previous research (e.g., Simanjuntak et al., 2014). The difference between this research and the previous research lies in the determination of samples and sampling 
DOI: 10.14807/ijmp.v12i5.1395

techniques. This research focused on the housewives who work full-time in the domestic sector as the research sample. In contrast, previous studies included housewives who both work in the public and domestic sectors. Another difference is the addition of lifestyle construct to increase the diversity of predictors that might affect consumer empowerment as suggested in prior research.

This study aims to analyze the difference in consumer education, lifestyle, and consumer empowerment between urban and rural areas, and to analyze the effect of consumer education and lifestyle on consumer empowerment. Based on these objectives, the following questions can be formulated: (1) How does the consumer education, lifestyle, and consumer empowerment differ between consumers living in urban and rural areas?; and (2) How does the consumer education and lifestyle affect consumer empowerment?

Based on the previous researches, the research framework is presented in Figure 1.

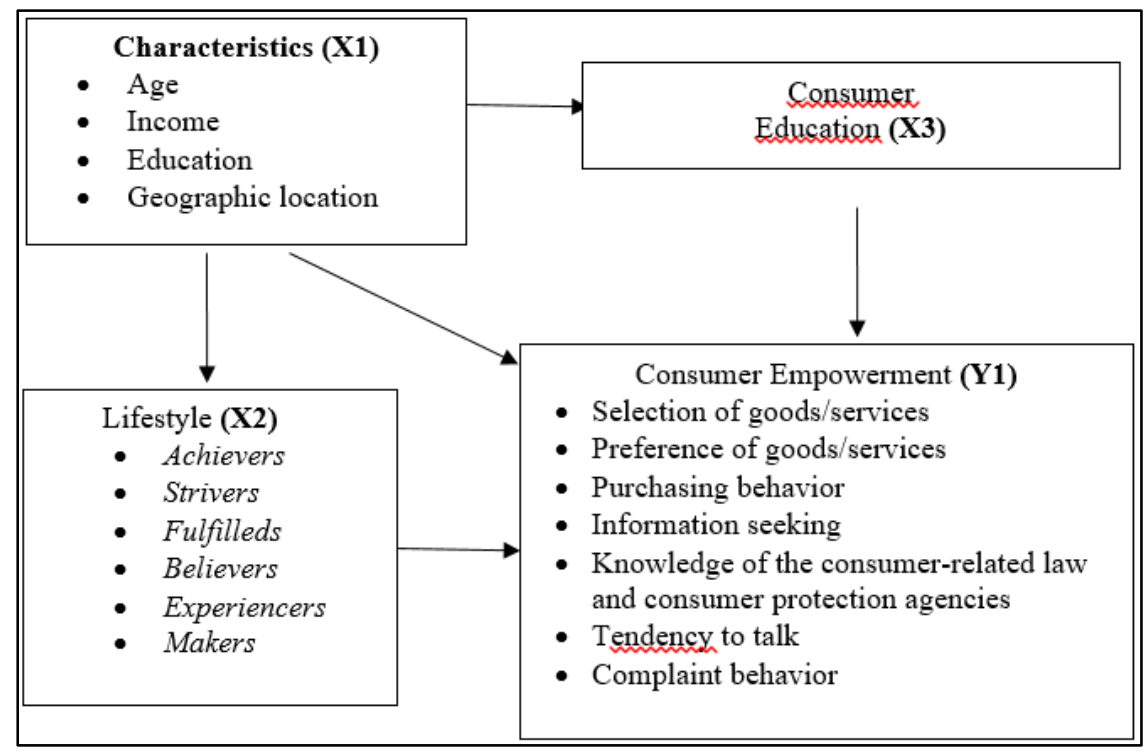

Figure 1: The research framework

The research hypotheses are as follows.

- H1: There is a significant difference in the consumer education, lifestyle, and consumer empowerment in urban and rural areas.

- H2: There is a significant influence of the consumer education and lifestyle on consumer empowerment.

\section{RESEARCH METHODOLOGY}

This research was a cross-sectional study with a survey method. The study was conducted in urban and rural areas of the Bogor region, West Java, Indonesia, which was selected purposively. The population and sample in this study were housewives who worked 
INDEPENDENT JOURNAL OF MANAGEMENT \& PRODUCTION (IJM\&P)

http://www.ijmp.jor.br

v. 12, n. 5, July-August 2021

ISSN: 2236-269X

DOI: 10.14807/ijmp.v12i5.1395

full-time in the domestic sector, organized, and managed finances, and made decisions on household spending.

Housewives were chosen as the research sample due to their most significant share of responsibility in determining the purchase decision of a household. Using the purposive sampling techniques, the total number of samples of 120 housewives was recruited in this study. Data were obtained through interviews using questionnaires and a showcard. Interviews were conducted directly by visiting respondents in their homes. Before the interview, respondents were first asked to participate in the research and signed the informed consent provided. The interview lasted between 15 and 30 minutes.

Primary data of the study included (1) sample characteristics (age, family income, length of education, and geographic location); (2) access to consumer education; (3) lifestyle; and (4) consumer empowerment (selection and preference of goods/services, purchasing behavior, information seeking, knowledge of the consumer-related law and consumer protection agencies, tendency to talk, and complaint behavior).

Data on age were obtained through an open-ended question, then grouped into the early adult (18-40 years), middle-aged adult (41-59 years), and older adult ( $\geq 60$ years) (Hurlock, 2013). The length of education included not completing school, not completing primary school ( $<6$ years), completed primary school (6 years), junior high school (9 years), senior high school (12 years), diploma (15 years), and undergraduate (16 years). Geographical locations were divided into urban and rural areas.

The consumer education refers to how often consumers receive consumer education. Data on this measure were obtained using an adapted and modified instrument (Simanjuntak et al., 2014). This instrument contains seven valid items $(\alpha=0.75)$ : seven items of consumer education information access $(\alpha=0.778)$, seven items of consumer education, and eight items of sources to obtain consumer education. The Likert scale was used to measure the access of consumer education ( 0 = never, 1 = sometimes, 2 = often, 3 = always). The composite scores were categorized into four categories: deficient (score $\leq 25$ ), low (score 26-50), good (score 5175), and excellent (score $>75$ ).

Lifestyle is an illustration of utilizing resources and developing a life orientation through appearance, hobbies, careers, education, social relationships, and consumption behavior. The consumer lifestyle measurement used the adopted instrument of VALS2 (Willbanks, 2005). It consists of six questions describing the dominant life orientation of the research participant. Participants chose the column that best describes their lifestyle: achievers, strivers, fulfilled, believers, makers, and experiencers. It aims to look at the most dominant 
INDEPENDENT JOURNAL OF MANAGEMENT \& PRODUCTION (IJM\&P)

http://www.ijmp.jor.br

v. 12, n. 5, July-August 2021

ISSN: 2236-269X

DOI: 10.14807/ijmp.v12i5.1395

lifestyle types in a population to give a general overview of the lifestyle characteristics that may affect purchasing behavior (Willbanks, 2005). Lifestyle was rated on a dummy score as follows: achievers (1) and non-achievers (0), strivers (1) and non-strivers (0), fulfilled (1) and non-fulfilled (0), believers (1) and non-believers (0), makers (1) and non-makers (0), experiencers (1) and non-experiencers (0).

Consumer empowerment refers to one's active search for information before buying, knowledge of the laws and consumer protection agencies, the ability to choose goods and services preferences when making a purchase, and the tendency to talk and complain if they are harmed or disappointed after purchase. The consumer empowerment instrument was adapted from the research instrument by Simanjuntak et al. (2014). The instrument is composed of seven valid items of goods/services selection $(\alpha=0.611)$, five items of domestic product preference $(\alpha=0.160)$, eight items of purchasing behavior $(\alpha=0.558)$, nine valid questions of information search $(\alpha=0.832)$, five valid questions of knowledge of the law and consumer protection agency $(\alpha=0.916)$, two valid questions talking tendencies $(\alpha=0.149)$, and ten valid questions of complaint behavior $(\alpha=0.852)$.

The consumer empowerment index is classified into three purchasing phases, namely pre-purchase, purchase, and post-purchase. The dimensions and items in the instrument explained above can be mapped into buying stages as follows: (1) Questions in the pre-purchase phase include seeking information (nine questions) and knowledge of the law and consumer protection agencies (five questions); (2) Question in the purchase phase include selection and preference of goods/services (12 questions) and buying behavior (eight questions); and (3) Questions in post-purchase phase include the tendency to talk or to hear opinions and complaints (two questions) and complaint behavior (10 questions).

The scale used to measure consumer empowerment is as follows: "correct" coded as (1) and "incorrect” coded as (0), "know” coded as (1) and “do not know” coded as (0), "yes" coded as (1) and "no" coded as (0), "local products" coded as (1) and "non-local products" coded as (0). A three-point Likert scale was used to measure dimensions of frequency with the following scoring: "never" rated on (0), "sometimes" rated on (1), "often" rated on (2), and "always" rated on (3). The total score of each dimension was then indexed to a scale of 0-100.

The weighting classification of each dimension of the consumer empowerment index is as follows: $40 \%$ of complaint behavior, $20 \%$ of information search, $15 \%$ of purchasing behavior, $10 \%$ of knowledge of the law and consumer protection agencies, $10 \%$ of selection and preference of goods/services, and $5 \%$ of the tendency to talk. The complaint behavior is categorized into five categories: deficient (score $\leq 25$ ), low (score 26-50), good (score 51-75), 
DOI: 10.14807/ijmp.v12i5.1395

and excellent (score $>75$ ). The consumer empowerment index in this study was categorized as follows: very unempowered (score 0.0-20.0), unempowered (score 20.1-40.0), fairly empowered (score 40.1-60.0), empowered (score 60.1-80.0) and very empowered (score 80.1100.0).

Data analysis was carried out using Microsoft Office Excel and Statistical Package for Social Science (SPSS) 22 for Windows. Next, descriptive analyses were used to obtain frequency, range, mean, and standard deviation. To compare the two regions, the independent sample T-test was performed to differentiate the age, length of education, total income, consumer education, and consumer empowerment index. The Mann-Whitney test was employed to examine the differences in lifestyle construct. In contrast, the multiple linear regression test was to examine the effect of consumer education and lifestyle on the consumer empowerment index.

\section{RESULT}

\subsection{Characteristics of Housewives}

\subsubsection{Age}

Housewives, both in urban and rural areas, were in the early adult category (18-40 years). Two-fifths (40\%) of the housewives in the rural area were in the middle adult category (41-59 years). The average age of housewives in urban areas $(\mathrm{M}=37.1$ ) was younger than those in rural households $(M=38.2)$. There was no significant difference between the two regions in terms of respondents' age $(p=0.502)$.

\subsubsection{Length of Education}

The length of education of most housewives in the urban area was at senior high school (12 years). The duration of the education of housewives in rural areas was equal to primary school (6 years). The highest education of housewives in urban areas was 16 years, while in rural areas, it was 12 years. The difference in the length of education between the two regions was significant $(p=0.000)$.

\subsubsection{Family Income}

The average family income in urban areas was Rp2,481,666.7 per month. This number was higher than in rural areas, which was Rp2,085,833.3 per month. The minimum income of families in both areas was Rp1,000,000 per month. The maximum family income in urban areas 
DOI: 10.14807/ijmp.v12i5.1395

was Rp7,000,000 per month and Rp6,000,000 per month in rural areas. Based on the test result, there was a significant difference in family income between the two regions $(p=0.048)$.

\subsection{Consumer Education}

\subsubsection{Consumer Educations Content}

The three content of consumer education that many housewives who live in urban and rural areas had access to was how to buy the right products services (urban $=73.3 \%$, rural $=$ $28.3 \%$ ), tips to be smart consumers (urban $=31.7 \%$, rural $=20 \%$ ) and complaints (urban $=$ $30 \%$, rural $=13.3 \%$ ). The apparent difference between housewives in urban and rural areas was found in information to buy the right product/service, information to complain, information about consumer protection laws and consumer protection agencies, and information to read labels.

\subsubsection{Source of Consumer Education Access}

The most widely used source of consumer education access by housewives in urban and rural areas was television (urban $=63.3 \%$, rural $=25 \%$ ), reference group including friends, neighbors, and family (urban $=48.3 \%$, rural $=31.7 \%$ ), and internet (urban $=43.3 \%$, rural $=$ $10 \%)$. Radio was a source of consumer education that was less desirable to housewives to gain access to consumer education (urban $=0 \%$, rural $=1.7 \%$ ). Based on the test results, there was a significant difference in consumer education sources in urban and rural areas, as follows: print media (brochures, leaflets, and booklets) $(p=0.000)$, print media (magazine and newspaper) $(p=0.008)$, banners $(p=0.002)$, internet $(p=0.000)$, and television $(p=0.000)$.

\subsubsection{The Intensity of Consumer Education}

The consumer education access obtained by housewives in urban (78.3\%) and rural areas (98.3\%) was considered very poor. The average score of the consumer education access in urban and rural areas was very low (urban $=13.5 \pm 13.8$, rural $=4.4 \pm 7.7$ ). The low access to consumer education in housewives living in rural areas is arguably due to difficulties in accessing consumer education and the lack of initiatives to seek consumer education information. In a prior study, factors that hamper information retrieval include lack of initiative, laziness, and ignorance (Juaini, Sinaga \& Rainathami, 2012). Based on the test results, the consumer education access in rural and urban areas proved to have a significant difference $(p$ $=0.000)$.

The consumer education materials with the most frequent accessed were how to buy the correct products/services (urban $=38.3 \%$, rural $=11.7 \%$ ), complaints (urban $=17.5 \%$, rural 
DOI: 10.14807/ijmp.v12i5.1395

$=3.3 \%$ ), the introduction of consumer protection agencies (urban $=13.3 \%$, rural $=1.7 \%$ ), the introduction of the Consumer Protection Act (urban $=11.7 \%$, rural $=3.3 \%$ ), and the introduction of consumer rights and obligations (urban $=10.8 \%$, rural $=3.3 \%$ ). The most rarely accessed information was how to read product labels (urban $=3.3 \%$, rural $=2.5 \%$ ) and tips to be a smart consumers (urban $=4.2 \%$, rural $=2.5 \%$ ).

\subsection{Lifestyle}

Willbanks (2005) divides the consumer lifestyle orientation into six groups, namely achievers, strivers, fulfilled, experiencers, believers, and makers. Achievers are consumers who have high incomes and love popular products. Strivers are low-income and status-oriented consumers. Fulfilled are adult consumers, responsible, educated, and always know the development of the outside world. Experiencers are high-income consumers who are active in social and sports activities and love new products. Believers are consumers who love local products and are active in social activities. Makers are consumers who have low incomes and love practical things.

Believers are the most common lifestyle among housewives in urban (46.7\%) and rural areas (73.3\%). Strivers are the lifestyle category with the fewest housewives in urban (1.7\%) and rural areas (0\%). Based on the test results, the significant difference was evident in the fulfilled lifestyle ( $p=0.001)$ and believers $(p=0.003)$ between housewives in rural and urban areas.

\subsection{Consumer Empowerment Index}

The average empowerment index of urban housewives $(41.9 \pm 17.01)$ was higher than that in rural areas $(28.6 \pm 12.6)$, and there was a significant difference between the two regions. More than two-fifths of housewives living in urban areas (45\%) were categorized as less powerful. As many as 55\% of housewives in rural areas were included in the category of helplessness. As many as $13.3 \%$ of urban housewives were included in the powerless category, while rural housewives were only $1.7 \%$. This condition reflects that housewives in urban areas were more empowered than those living in rural areas.

On average, each dimension of the consumer empowerment index in urban areas had a higher tendency than in rural areas. The average of the highest dimension of the consumer empowerment index is the dimension of urban buying behavior, which is 89.1, whereas the lowest in the knowledge dimension of law and the consumer protection institution in the rural area which is 4.0 (Table 1 ). 
INDEPENDENT JOURNAL OF MANAGEMENT \& PRODUCTION (IJM\&P)

http://www.ijmp.jor.br

v. 12, n. 5, July-August 2021

ISSN: 2236-269X

DOI: 10.14807/ijmp.v12i5.1395

Table 1: Average score, standard deviation, and significance value of consumer empowerment index

\begin{tabular}{lccc}
\hline Dimension & Urban & Rural & $p$ \\
\hline Search information & $51.8 \pm 30.3$ & $45.7 \pm 20.1$ & 0.263 \\
$\begin{array}{l}\text { Knowledge of consumer } \\
\text { protection laws and institutions }\end{array}$ & $24.3 \pm 33.4$ & $4.0 \pm 15.5$ & $0.000^{* *}$ \\
$\begin{array}{l}\text { Choice and preference of } \\
\text { goods/services }\end{array}$ & $64.7 \pm 20.6$ & $51.7 \pm 16.9$ & $0.000^{* *}$ \\
Purchase behavior & & & \\
Tendencies to talk & $89.1 \pm 28.7$ & $51.5 \pm 19.9$ & $0.000^{* *}$ \\
Complaint behaviour & $56.4 \pm 20.8$ & $48.9 \pm 26.9$ & 0.090 \\
\hline
\end{tabular}

Note: *significant on $p<0.05 ; * *$ significant on $p<0.01$

\subsection{Factors Affecting the Consumer Empowerment Index}

The classical assumption test was performed to meet the predetermined requirements before performing the regression test, including normality, multicollinearity, heteroscedasticity, and autocorrelation tests. The data in this research spread around the diagram and followed the regression model. Thus, the normality assumption was fulfilled. Also, there was no multicollinearity between variables. The best model for the regression test was chosen based on the enter method. The variables studied were also free from heteroscedasticity, marked with points on the scatterplot spread above and below the Y-axis. The variables were also free from autocorrelation as the value of Durbin Watson approached the value of +2 .

The result of multiple regression analysis showed that there was a significant influence of the independent variables (age, income, duration of education, geographical location, fulfilled lifestyle, and consumer education access) on the consumer empowerment index, as many as $74.7 \%$ (adjusted R2 $=0.747$ ). The rest of the $25.3 \%$ were influenced by other variables that were not examined in this study. Partially, education had a significant and positive effect on consumer empowerment by 3.866 times $(\beta=0.255 ; p=0.002)$. That is, any increase in oneyear-long education of the housewives will increase the consumer empowerment index by 3.866 points.

The result of the regression analysis showed that there was a significant and positive effect of consumer education on the consumer empowerment index by 0.659 times $(\beta=0.486$; $p=0.000)$. Thus, every increase of one point of consumer education access will increase the consumer empowerment index by 0.659 points (Table 2). The results of this study are in line with Simanjuntak et al. (2014), where the education and the consumer education show a significant and positive impact on consumer empowerment. The regression equation of this model is as follows: 
INDEPENDENT JOURNAL OF MANAGEMENT \& PRODUCTION (IJM\&P)

http://www.ijmp.jor.br

v. 12, n. 5, July-August 2021

ISSN: 2236-269X

DOI: 10.14807/ijmp.v12i5.1395

$\mathrm{Y}=21.373-0.136 \mathrm{X}_{1}+1.101 \mathrm{X}_{2}+3.866 \mathrm{X}_{3}-3.452 \mathrm{D}_{1}+1.884 \mathrm{D}_{2}+0.659 \mathrm{X}_{4}+\varepsilon$

Table 2: Results of the multiple regression analysis of factors that affect the consumer empowerment index

\begin{tabular}{|c|c|c|c|}
\hline \multirow{2}{*}{ Variables } & \multicolumn{2}{|c|}{ Consumer empowerment } & \multirow{2}{*}{$p$} \\
\hline & B & Beta & \\
\hline Constants & 21.373 & & \\
\hline Age $\left(\mathrm{X}_{1}\right)$ (years) & -0.136 & -0.072 & 0.282 \\
\hline Income ( $\left.\mathrm{X}_{2}\right)$ (IDR/month) & 1.101 & 0.077 & 0.267 \\
\hline Length of education $\left(\mathrm{X}_{3}\right)$ (years) & 3.866 & 0.255 & $0.002^{* *}$ \\
\hline $\begin{array}{l}\text { Geographical location }\left(D_{1}\right)(0= \\
\text { rural, } 1=\text { urban) }\end{array}$ & -3.452 & 0.106 & 0.140 \\
\hline $\begin{array}{l}\text { Lifestyle }\left(D_{2}\right)(0=\text { non fulfilleds, } 1= \\
\text { fulfilleds })\end{array}$ & 1.884 & 0.036 & 0.589 \\
\hline $\begin{array}{l}\text { Consumer education Access }\left(\mathrm{X}_{4}\right) \\
\text { (time/month) }\end{array}$ & 0.659 & 0.486 & $0.000^{* *}$ \\
\hline F & & 791 & \\
\hline Adj. $R^{2}$ & & 747 & \\
\hline Sig & & $00 * *$ & \\
\hline
\end{tabular}

\section{DISCUSSION}

This study found that there was a significant difference in the consumer education and consumer empowerment between housewives in urban and rural areas. However, there was no significant difference in lifestyle between the two regions. This finding is in line with the study by Simanjuntak et al. (2014), where there was a significant difference in the frequency of consumer education between districts and municipalities. Housewives who live in urban and rural areas rarely access consumer education. This can be seen from the consumer education access in the deficient category in the urban area (78.35\%) and rural (98.3\%). The situation is suspected because of the socialization of consumer education has no yet optimally implemented in rural areas of Indonesia.

Consumer education can be obtained through printed media sources, reference groups, and electronic media (Benn, 2004). Three sources of information that many housewives in urban and rural areas had access to consumer education were television, reference groups, and the internet. This finding is in line with the results of research by Mishra and Kumar (2012), suggesting that access information that most consumers were interested in was television. Radio was a source of access to consumer education rarely used by housewives in urban ( $0 \%)$ and rural areas (1.7\%).

Reference groups (friends, neighbors, and families) are the second most accessible source for housewives to obtain consumer education. Only $1.7 \%$ of housewives in rural areas used the internet as a source to access consumer education. This is in line with the general picture of housewives in rural areas who are less likely to use or get access to the internet. The 
INDEPENDENT JOURNAL OF MANAGEMENT \& PRODUCTION (IJM\&P)

http://www.ijmp.jor.br

v. 12, n. 5, July-August 2021

ISSN: 2236-269X

DOI: 10.14807/ijmp.v12i5.1395

ease of internet usage is determined by networks in a region and the ability of housewives to operate it (Pitt et al., 2002).

The socialization of consumer education is one of the efforts to increase consumer awareness of their rights (Isaac \& Zabil, 2012). The percentage of consumer education materials about the introduction of the rights and obligations of consumers in rural areas was still low (1.7\%). According to Mcgregor (2005), access to consumer education may increase consumer knowledge about their rights. Among factors that influence the high-intensity level of information access is self (Lyon et al., 2002). Further, this factor can be seen from the lifestyles of consumers who like or dislike new information; this characteristic is portrayed among groups with fulfilled lifestyles (Willbanks, 2005).

There was a significant difference between housewives with fulfilled $(p=0.001)$ and believer lifestyles $(p=0.003)$. Consumers with believer lifestyles tend to be obedient and orderly to the values determined (Willbanks, 2005). Also, consumers with believer lifestyles reflect value-conserved consumers but are slightly concealed against new information (KIM et al., 2003). The lifestyle orientation of believers is less reflective of consumer empowerment. This trait can be seen from the characteristics of the consumers who are obedient and responsible to a value but do not have extensive knowledge and tend to be passive.

On the other hand, the lifestyle that reflects the hallmark of consumer empowerment is fulfilled. The fulfilled lifestyle is represented by the mature, responsible, firm, professional, educated, active, high-income consumers, knowing the development of the outside and the open with new information and social change (Thogersen, 2005). The fulfilled lifestyle can reflect a powerless consumer, which means a compelling consumer has much knowledge and ability to manage his knowledge with firmness in response to change. Sun and $\mathrm{Wu}$ (2007) found a significant difference between Chinese urban and rural consumers in the use of products that reflect the orientation of life. Urban consumers prefer products that reflect the ability of the resources they possess. Also, there is a marked difference in the lifestyle of Indian consumers in deciding product purchases (Sehrawet \& Kundu, 2004).

Consumer empowerment is the consumer skill in defending his rights and in making decisions (Boje \& Rosile, 2001). The average consumer empowerment index for housewives who live in urban areas is higher than that in rural areas. The condition is reflected by the number of housewives in urban areas who were categorized as empowered (13.3\%), whereas only $1.7 \%$ were identified in rural areas. The average difference in the consumer empowerment index is shown in its dimensions in which urban housewives show higher scores than rural housewives. The highest average score of the dimension of the consumer empowerment index 
INDEPENDENT JOURNAL OF MANAGEMENT \& PRODUCTION (IJM\&P)

http://www.ijmp.jor.br

v. 12, n. 5, July-August 2021

ISSN: 2236-269X

DOI: 10.14807/ijmp.v12i5.1395

is buying behavior. In contrast, the lowest average score is the knowledge of consumer protection laws and institutions.

Knowledge of law and consumer protection institutions for housewives in urban and rural areas was still low. In terms of the difference between the two regions, a higher percentage score was found among urban housewives. Only 3.3\% of housewives in rural areas knew about rights as consumers; this finding in line with the results of research by Simanjuntak et al. (2015), which found that more than half of housewives in urban areas (52.5\%) and a small proportion of those in rural areas (7.5\%) are aware of laws governing consumer protection.

The proportion of housewives who tell their bad experiences after unsatisfying product purchases was still low. The finding indicated by the low percentage score of housewives who reported "always" in response to the question "telling my bad purchase experiences to others." This situation will undoubtedly affect the behavior of complaints. According to Velázquez et al. (2006), complaining influences the intention of complaints.

The behavior of complaints in Indonesia is still low, indicated by the number of cases of loss, but only a few who complain (Nurhayati \& Elisabeth, 2011). According to Kim, Wang, and Mattila (2010), housewives who live in urban and rural areas choose to withdraw from such adverse conditions by discontinuing products or switching to other products rather than making a complaint to the business actors. A similar finding is also shown from the in-depth interviews in which influences which had felt disadvantaged when buying food products chose not to file a complaint nor ask for compensation. As suggested by Wojciszke et al. (2009) and Kauffeld (2009), there are still many respondents who do not complain at the time of disappointment after purchase.

The access of education had a significant positive effect on consumer empowerment. In contrast, the lifestyle did not have a significant and positive impact on consumer empowerment. The results of this study are in line with the research of Simanjuntak et al. (2013) as well as Hunter and Garnefeld (2008), suggesting that the length of education and the access of consumer education had a significant and positive impact on consumer empowerment. Also, this finding supports the results of other studies, including Nardo et al. (2011); Rahman and Naoroze (2007); and Primary (2013), where the level of education affects the consumer empowerment.

Age had no significant effect on consumer empowerment, which is not in line with the study of Nardo et al. (2014) and Shibly (2009), who found that age was negatively associated with consumer empowerment. Also, this finding is in contrast with Tyde and Chole (2010), who stated that empowerment was influenced by income. According to Ratnawati (2011), 
INDEPENDENT JOURNAL OF MANAGEMENT \& PRODUCTION (IJM\&P)

http://www.ijmp.jor.br

v. 12, n. 5, July-August 2021

ISSN: 2236-269X

DOI: 10.14807/ijmp.v12i5.1395

geographic location affected women empowerment; this is not in line with the results of this study, which found no significant effect of the geographic location on consumer empowerment. Lifestyle had no significant effect on consumer empowerment; this is arguably due to lifestyle depicts only the orientation of life and does not show the skills and assertiveness that fit the picture of the powerless consumer.

The contribution of this research to the development of science may provide a reference for scientists or researchers, especially in consumer science, that focuses on the efforts of consumer empowerment through consumer education. The government, especially the Consumer Dispute Settlement Agency (BPSK), the Directorate of Standardization and Consumer Protection, the Ministry, and the Indonesian Consumer Protection Foundation (YLKI), are expected to contribute to providing information on the government efforts in disseminating education and consumer protection. Also, the results of this study may serve information and insight to promote smart, critical, educated, and wise consumers in Indonesia.

\section{CONCLUSIONS}

In conclusion, the results of this research partially answer the first research question. The access of consumer education among urban and rural housewives in this study areas is still low, and there is a significant difference between the two regions. Consumer education on knowledge of the Consumer Protection Act and consumer protection institution is also low. The primary sources to obtain information regarding consumer education for housewives are television and reference groups (friends, family, and neighbors). The fulfilled lifestyle describes consumers who are very concerned about new information. Therefore, this lifestyle approaches the characteristics of consumer empowerment. There is a significant difference in the lifestyle of the fulfilled and the believer between the two regions. The lifestyle that most held by housewives in rural and urban areas is believers..

The level of customer empowerment in urban and rural areas is still low, and there is a significant difference between the two regions. The average empowerment of housewives in urban areas is better than in rural areas. Some facts indicating that housewives living in urban and rural areas have low empowerment level are: (1) The low access of consumer education, especially regarding consumer rights, the introduction of consumer protection law and agencies; (2) poor understanding of goods selection according to exchange rate; (3) poor understanding of consumer financial literacy; (4) poor understanding of the standard clause; and (5) very lack of assertiveness in defending their rights and lack of willingness to file a complaint and compensation. 
DOI: 10.14807/ijmp.v12i5.1395

The results of this research also partially answer the second research question. Factors that affect consumer empowerment among housewives in urban and rural areas are the length of education and the access of consumer education whereas lifestyle and characteristics of the sample (age, income, geographic location) do not affect consumer empowerment. Therefore, consumer empowerment is strongly influenced by consumer knowledge either through formal or informal education.

Based on the findings of this study, increasing the access of consumer education is required to improve consumer empowerment. Content of consumer education that needs to be promoted includes the introduction of the law and consumer protection agencies, and the introduction of consumer rights and obligations. The socialization of consumer education in the form of direct counseling may serve as an appropriate empowerment effort for housewives in urban and rural areas.

This is because housewives have a high interest in getting consumer education provided directly by educators than through print media. Also, efforts to empower consumers should be made by establishing cooperation between the government and related institutions that are influential for a group of housewives in each region. This effort is expected to realize the socialization of consumer education in every region.

\section{REFERENCES}

Australian Government. (2011). Australia Consumer Survey 2011. Australia: Australian Government, ISBN: 978-0-642-74680-1.

Benn, J. (2004). Consumer education between 'consumership' and citizenship experiences from studies of young people. International Journal of Consumer Studies, 28(2), 108-116. DOI: $10.1111 /$ j.1470-6431.2003.00364.x.

Boje, D. M., \& Rosile, G. A. (2001). Where is the power in empowerment? Answer from flollent and clegg. Journal of Applied Behavioral Sciences, 37(1), 9-117. DOI: $10.1177 / 0021886301371006$.

Chandrasekhar. (2012). Consumer buying behavior and brand loyalty in rural markets. Journal of Business and Management(42), 50-67. DOI: 10.9790/487X-0325067.

Hunter, G. L., \& Garnefeld, I. (2008). When does consumer empowerment lead to satisfied customers? Some Mediating and Moderating Effects of the Empowerment-Satisfaction Link. Journal of Research for Consumers, 15(1), 1-4.

Ishak, S., \& Zabil, N. F. (2012). Impact of consumer awareness and knowledge on effective consumer behavior. Journal of Asian Social Science, 8(13), 263-296. DOI:

10.5539/ass.v8n13p108.

Juaini, A., Sinaga, D., \& Rainathami, H. (2012). Information seeking behavior by users in the Cistral UNPAD library circulation service. E-journal Mahasiswa Universitas Padjadjaran, 1(1), 1-15. 
DOI: 10.14807/ijmp.v12i5.1395

Kauffeld, S. (2009). Complaint, and solution-oriented circles: interaction patterns in workgroup discussions. European Journal of Work and Organizational Psychology, 18(3), 267-294. DOI: 10.1080/13594320701693209.

Kim, M .G., Wang, C., \& Mattila, D. A. (2010). The relationship between consumer complaining behavior and service recovery. International Journal of Contemporary Hospitality Management, 22(7), 975-991. DOI: 10.1108/09596111011066635.

Kim, Y., Sullivan, P., Trotter, C., \& Forney, J. (2003). Lifestyle shopping center: A retail evolution of the $21^{\text {St }}$ century. Journal of Shopping Center Research, 10(2), 61-88.

Kurniawan. (2012). Problems and constraints of consumer dispute resolution through BPSK (consumer dispute resolution agency).. Jurnal Dinamika Hukum, 12(1), 1-45. DOI: 10.20884/1.jdh.2012.12.1.113.

Lyon P., Kinney D., \& Colquhoun A. (2002). Experience, change, and vulnerability: consumer education for older people revisited. International Journal of Consumer Studies, 26(2), 178-187. DOI: 10.1046/j.1470-6431.2002.00240.x.

Mcgregor, S. L. T. (2005). Sustainable consumer empowerment through critical consumer education: a typology of consumer education approaches. International Journal of Consumer Studies, 2(95), 437-447. DOI: 10.1111/j.1470-6431.2005.00467.x.

Mishra S. K., \& Kumar M. (2011). How mutual fund investors’objective and subjective knowledge impacts their information search and processing behaviour. Journal of Financial Services Marketing, 16(1), 27-41. DOI: 10.1057/fsm.2011.1.

Nardo, M., Loi, M., Rosati, R., \& Manca, A. (2011). The consumer empowerment index: a measure of skills, awareness, and engagement of European consumers. JRC Scientific and Technical Reports. Luxembourg: Publications Office of the European Union, ISBN: 97892-79-19926-4, P. 211-229. DOI: 10.2788. 9102.

Nurhayati, I., \& Elisabeth, Y. M. (2011). Consumer protection through formal and informal social control. Jurnal Ekonomi dan Bisnis, 10(1), 71-76.

Paim, L., Masud, J., \& Haron, S. A. (2012). Research on consumer Well-Being in Malaysia. Journal Family and Economic, 3(35), 227-230.

Pitt, L., Berthonb, P., Watson, R., \& Zinkhan, G. (2002). The internet and the birth of real consumer power. Business Horizons, 45(2), 7-14.

Pratama, C. (2013). Factors influencing the empowerment of Joho village women on the slope of Mount Wilis. Jurnal Kebijakan dan Manajemen Publik, 1(1), 12-19.

Rahman, M. H., \& Naoroze K. (2007). Women empowerment through participation in an aquaculture: experience of a large scale technology demonstration project in Bangladesh. Journal of Social Science, 3(4), 164-171. DOI: 10.3844/jssp.2007.164.171.

Ratnawati, S. (2011). Empowerment model of rural poor women through entrepreneurship development. Jurnal Kewirausahaan, ISSN. 1978-4724, 5(2), 1-10.

Safari, A., \& Simanjuntak, M. (2020). Consumer Protection: An Introduction. Safari, A,. Dalimunthe, A.R.L,. Anggraini, A.T,. Parman, A,. Muslim, E,. Simanjuntak, M. Unboxing Consumer Protection. Bogor: IPB Press. pp. 1-24

Sehrawet, M., \& Kundu, S. C. (2004). Consumption patterns of India. International Journal of Consumers Studies, 3(3), 630-638. 
DOI: 10.14807/ijmp.v12i5.1395

Shibly, H. A. (2009). A characterization of consumer empowerment drawn from three views of power. ABAC Journal, 29(3), 65-74.

Simanjuntak, M. (2015). Consumer empowerment index among undergraduate students of Bogor Agricultural University, Indonesia. Asian Journal of Business and Management, 3(3), 183-191.

Simanjuntak, M. (2019). Generation Y's complaint behavior toward online shopping. Independent Journal of Management \& Production, 10(1), 101-116.

http://dx.doi.org/10.14807/ijmp.v10i1.839

Simanjuntak, M., \& Musyifah, I. (2016). Online shopping behavior on Generation Y in Indonesia. Global Business Finance Review, 21(1), 33-45.

Simanjuntak, M., \& Putri, R.R.E. (2020). How empowered is the consumer in telecommunications sector: the role of socio-demographic and lifestyle? Indonesian Management Journal, forthcoming.

Simanjuntak, M., \& Putri, S.A. (2018). Consumer empowerment index of electronic product buying. Independent Journal of Management \& Production, 9(4), 1165-1183. http://www.ijmp.jor.br/index.php/ijmp/article/view/814

Simanjuntak, M., \& Umiyati, S. (2021). The effect of demographic, social, and economic characteristics on consumer empowerment in education institutions. Independent Journal of Management \& Production. forthcoming.

Simanjuntak, M., \& Yuja, S. (2021). Understanding The Consumer Empowerment In Health Service. Independent Journal of Management \& Production. forthcoming.

Simanjuntak, M., Amanah, S., Puspitawati, H., \& Asngari, P. S. (2013). Modelling consumer empowerment level. Economic Journal of Emerging Markets, 5(2), 109.119. DOI:

10.20885/ejem.vol5.iss2.art4.

Simanjuntak, M., Amanah, S., Puspitawati, H., \& Asngari, P. S. (2014). Consumer empowerment profile in rural and urban area. Asean Marketing Journal, 15(1), 38-49. DOI: 10.21002/amj.v6i1.3611.

Simanjuntak, M., Amanah, S., Puspitawati, H., \& Asngari, P. S. (2014). Study of consumer education in Bogor, Indonesia. Asian Journal of Business and Management, 2(5), 481-490.

Simanjuntak, M., Hamimi, U.K. (2019). Complaint handling and Word-of-Mouth (WOM) communication. Journal of Family \& Consumer Science, 12(1), 75-86. https://doi.org/10.24156/jikk.2019.12.1.75

Simanjuntak, M., Utami, F. S., \& Johan I. R. (2015). Vulnerability of consumers and purchasing behavior of packaging food products. Jurnal Ilmu Keluarga \& Konsumen, 8(3), 193-273. DOI: 10.24156/jCEI.2015.8.3.193.

Suja, S. (2012). Women empowerment through self-help group an evaluative study. Sona Global Management Review, 6(3), 35-84.

Sun, T., \& Wu, G. (2007). Consumption patterns of Chines urban and rural consumers. Journal of Marketing, 21(3), 245-253. DOI: 10.1108/07363760410542156.

Tayde, V. V., \& Chole, R. R. (2010). Empowerment appraisal of rural women in marathwada region of Maharashtra state. Journal of Consumer, 10(1), 1-45.

Thogersen, J. (2005). How may consumer policy empower consumers for sustainable lifestyles?. Journal of Consumer Policy, 28(3), 143-178. 
Velázquez, B. M., Contri, G. B., Saura, I. G., \& Blasco, M. F. (2006). Antecedents to complaint behavior in the context of restaurant goers. International Review of Retail, Distribution and Consumer Research, 16(5), 493-517. DOI: 10.1080/09593960600980030.

Wandani, D., \& Simanjuntak, M. (2019). Personality, motivation, and behavior of complaints based on ethnicity. Journal of Family \& Consumer Science, 12(3), 236-247. https://doi.org/10.24156/jikk.2019.12.3.236

Wathieu, L., Benner, L., \& Carmon, Z. (2002). Consumer control and empowerment. Marketing Letters, 13(3), 297-305.

Willbanks, J. K. (2005). Exploring lifestyle orientation, attitude toward lifestyle merchandising, and attitude toward lifestyle advertising as predictor of behavioral intention to purchase lifestyle home furnishing products. Thesis. Texas: University of North Texas.

Wojciszke., Baryła, B., \& Sudziarska, A. S. (2009). Saying is experiencing: Affective consequences of complaining and affirmation. Journal of Polish Psychological Bulletin, 40(2), 4-84. DOI: 10.2478/s10059-009-0008-0.

Wright, L. T., Newman, A., \& Dennis, C. (2006). Enhancing consumer empowerment. European Journal of Marketing, 40(10), 925-935. DOI: 10.1108/03090560610680934. 